\title{
The Production of Tannin Acyl Hydrolase from Aspergillus niger
}

\author{
YUNITA ARIAN SANI ANWAR, HASIM, AND I MADE ARTIKA*
}

Department of Biochemistry, Institut Pertanian Bogor, Darmaga Campus, Bogor 16680, Indonesia

\begin{abstract}
The aim of this research was to produce tannin acylhydrolase (tannase) from Aspergillus niger isolated from cacao pod. The first step of the study included determination of optimal $\mathrm{pH}$, temperature, and incubation period to produce tannase. Optimal conditions obtained for tannase production were $\mathrm{pH} \mathrm{5.5}$, a temperature of $28{ }^{\circ} \mathrm{C}$ and an incubation period of 3 days. Optimization of production medium was conducted. The media tested were solid and liquid wheat flour media with a concentration of tannic acid as inducer at $0,3,5$, and $7 \%$ (wt/vol). The best production medium was solid medium with tannic acid concentration of $5 \%$ (wt/vol).
\end{abstract}

Key words: tannase, Aspergillus niger, solid state fermentation, liquid state fermentation, tannic acid inducer

Tannin acylhydrolase also known as tannase (EC 3.1.1.20) is a hydrolytic enzyme that catalyses the hydrolysis of (hydrolysable) tannins releasing glucose and gallic acid. Tannins are natural compounds which have a number of phenolic hydroxyl groups and can precipitate protein. The ability of these compounds to precipitate protein generates some problems. Tannins are capable of interacting with protein and crude-fibres and also with digestive enzymes so that they could interfere with the digestion process that can inhibit the growth of livestock (Butler and Rogler 1992).

Tannase is extensively used in food and medical industries. In the food industry, the enzyme is used in the manufacture of instant tea, as a clarifying agent of wine, fruit juices, and in reduction antinutritional effects of tannins in animal feed. In Brazil, tannase has a potential use for reducing astringency of cashew apple juice. In the medical industry, tannase is used in the production of gallic acid, a substrate for the chemical synthesis of propyl gallate and trimethoprim (Pinto et al. 2001).

A number of microorganisms such as fungi, bacteria, and yeast are known tannase producers. Species belonging to the Aspergillus and Penicillium genuses were reported as the best tannase producers (Pinto et al. 2001). Purnama (2004) found that Aspergillus niger isolated from cacao pod reduces tannin levels up to $79.3 \%$ (wt/wt). Hatamoto et al. (1996) isolated and characterized a tannase gene from Aspergillus oryzae. The gene was found to encode a protein of 588 amino acids. The tannase gene product was translated as a single polypeptide and processed by cleavage into two tannase subunits linked by disulfide bonds. The native tannase was concluded to consist of four pairs of the two subunits, forming a hetero-octamer with a molecular weight of about 300,000 (Hatamoto et al. 1996). Sabu et al. (2005) reported that the optimum temperature for fungal tannase activity was between 30 and $40{ }^{\circ} \mathrm{C}$. The enzyme showed optimum activity at $\mathrm{pH}$ value between 5.0 and 6.0.

Tannase is an extracellular enzyme that needs an inducer to increase the enzyme synthesis. Several studies on optimum production of tannase by moulds have been conducted. Tannase was found to be induced by tannic acid and some of its derivatives (Aguilar et al. 2001). Similarly,

\footnotetext{
${ }^{*}$ Corresponding author, Phone/Fax: +62-251-423267, E-mail: imart171@yahoo.com
}

Sanchez (2003) reported that tannase production increases when the culture media contains $3 \%(\mathrm{wt} / \mathrm{vol})$ of tannic acid. The tannase activity obtained in these media reached $7.45 \mathrm{U} \mathrm{ml}^{-1}$.

In the present study tannase was produced using $A$. niger isolated from local cacao pod. Optimization of production medium and characterization of the resultant tannase were carried out. The optimum concentration for induction was also determined.

\section{MATERIALS AND METHODS}

Maintenance of Culture. A strain of Aspergillus niger was obtained from the stock collection of the Engineering and Bioprocess Laboratory, Institut Pertanian Bogor. The strain was isolated from cacao pod collected from a cacao plantation in Bogor, West Java. Potato Dextrose Agar (PDA) (Difco) slants were used for maintenance of $A$. niger with incubation at $28^{\circ} \mathrm{C}$ for 6 days. Fully sporulated slants not in use were stored at $4{ }^{\circ} \mathrm{C}$. The slants were subcultured routinely once every three weeks.

Preparation of Spore Inoculum. Fungal spore inoculum was prepared by adding $10 \mathrm{ml}$ of sterile distilled water containing $0.1 \%$ ( $\mathrm{vol} / \mathrm{vol}$ ) Tween 80 to a fully sporulated culture. The spores were dislodged using a sterile inoculation loop under strict aseptic condition and then vortexed in a slanted position. The volume of $1 \mathrm{ml}$ of the prepared spore suspension was used as inoculum with concentration of $3 \mathrm{x}$ $10^{7}$ spores.

Preparation of Production Medium. Tannase production was carried out using both solid and liquid media. The solid medium for solid state fermentation (SSF) was prepared as follows: A mass of $5 \mathrm{~g}$ of wheat flour was taken into a $125 \mathrm{ml}$ Erlenmeyer flask and moistened with $5 \mathrm{ml}$ of Czapeck medium $\left(\mathrm{NaNO}_{3} 3 \mathrm{~g} \mathrm{l}^{-1}, \mathrm{KCl} 0.5 \mathrm{~g} \mathrm{l}^{-1}, \mathrm{MgSO}_{4} \cdot 3 \mathrm{H}_{2} \mathrm{O} 0.348 \mathrm{~g} \mathrm{l}^{-1}\right.$, $\mathrm{FeSO}_{4} \cdot 7 \mathrm{H}_{2} \mathrm{O} 0.01 \mathrm{~g} \mathrm{l}^{-1}, \mathrm{~K}_{2} \mathrm{HPO}_{4} \cdot 3 \mathrm{H}_{2} \mathrm{O} 1.301 \mathrm{~g} \mathrm{l}^{-1}$, and tannic acid $\left.30 \mathrm{~g} \mathrm{l}^{-1}\right)$. The liquid medium used for tannase production was the Czapeck medium with $70 \mathrm{~g} \mathrm{l}^{-1}$ glucose as carbon source.

Optimization of Condition for Tannase Production. Determination of optimal $\mathrm{pH}$, temperature and incubation period for tannase production was carried out using solid state fermentation. Variable parameters for the enzyme 
production were $\mathrm{pH}(4,4.5,5,5.5,6)$, temperature $(26,28,30$, $32^{\circ} \mathrm{C}$ ), and incubation period (1-5 days).

Extraction of Crude Enzyme. Tannase was extracted from the fermented substrate by adding $50 \mathrm{ml}$ of distilled water containing $0.01 \%$ (vol/vol) Tween 80 . Contents were mixed well using a magnetic stirrer. Crude enzyme was separated from fermented matter by centrifugation (Beckman J2-21 rotor) at $7700 \mathrm{~g}, 4^{\circ} \mathrm{C}$, for $20 \mathrm{~min}$. The supernatant was separated by filtration through Whatman no. 1 and the filtrate was collected in bottles for further studies.

Tannase Assay. Tannase activity was determined by method of Libuchi et al. (1966). The substrate solution, containing $1 \mathrm{ml}$ of $0.35 \%$ ( $\mathrm{wt} / \mathrm{vol}$ ) purified tannic acid in $0.05 \mathrm{M}$ citrate buffer ( $\mathrm{pH}$ ) was preincubated at $30^{\circ} \mathrm{C}$ for about $5 \mathrm{~min}$. Enzyme solution $(0.25 \mathrm{ml})$ was added followed by incubation at $30{ }^{\circ} \mathrm{C}$ for $15 \mathrm{~min}$. The blank solution was prepared by adding citrate buffer in place of the enzyme. Into the solution, $5 \mathrm{ml}$ of $95 \%$ ( $\mathrm{vol} / \mathrm{vol}$ ) ethanol was added followed by mixing in order to stop the reaction. After this, $0.25 \mathrm{ml}$ aliquots of the reaction and blank mixtures were transferred into respective test tubes. Ethanol solution was added to all tubes and the tubes were mixed thoroughly. Absorbance was measured at $310 \mathrm{~nm}$. One unit of enzyme activity was defined as the amount of enzyme required to hydrolyze $1 \mu \mathrm{mol}$ of the ester bond in $1 \mathrm{~min}$.

Optimization of Medium for Tannase Production. In the present study, the effect of different tannic acid concentrations on tannase production in solid state fermentation and liquid surface fermentation was studied. For these purposed, the tannic acid concentration in the Czapeck medium used for preparation of solid and liquid production media was varied from $0,30,50$, and $70 \mathrm{~g} \mathrm{l}^{-1}$. The culture was incubated at $28^{\circ} \mathrm{C}$ on rotary shaker $(150 \mathrm{rpm})$ for $72 \mathrm{~h}$. Tannase assay was performed using method of Libuchi et al. (1966) and total soluble protein was determined by the method of Bradford (1976).

\section{RESULTS}

Effect of Temperature. Temperature for the growth studies was $26,28,30$, and $32^{\circ} \mathrm{C}$. Maximum tannase activity $\left(0.167 \mathrm{U} \mathrm{ml}^{-1}\right)$ was obtained at growth temperature of $28^{\circ} \mathrm{C}$. Thereafter a declining trend was observed, as shown in Fig 1.

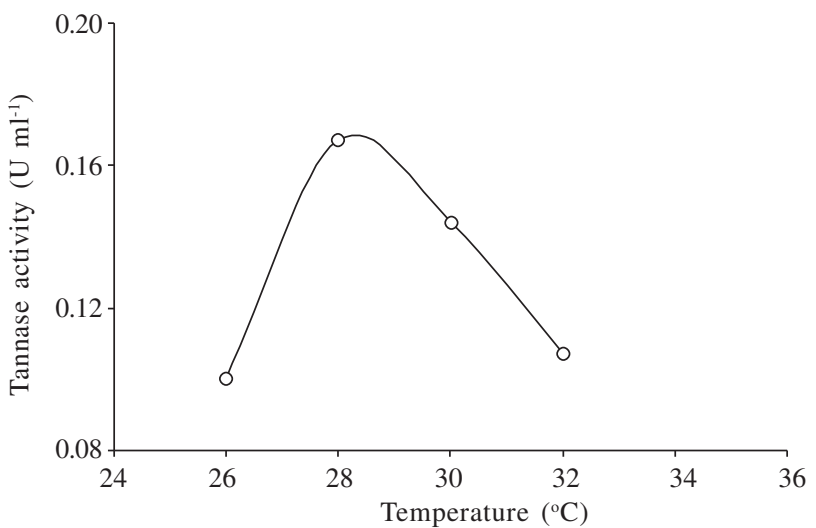

Fig 1 Effect of temperature on tannase activity at $\mathrm{pH} 5.5$ and 3 days incubation period.
Effect of pH. To determine effect of $\mathrm{pH}$ of the growth medium on tannase production, a range of $\mathrm{pH}$ of the medium was used being $4,4.5,5,5.5$, and 6 . The optimum $\mathrm{pH}$ of medium was found to be 5.5 (Fig 2).

Effect of Incubation Period. Incubation period is the most important parameter for maximum tannase production. The optimum incubation period was obtained at $72 \mathrm{~h}$. Up to $72 \mathrm{~h}$ there was a rise in tannase activity, after which a decrease was observed (Fig 3).

Effect of Media and Tannic Acid Concentration. This research tested solid and liquid media with an inducer concentration varied at $0,3,5$, and $7 \%(\mathrm{wt} / \mathrm{vol})$. The maximum enzyme activity was obtained with the solid medium with a tannic acid (inducer) concentration of 5\% (wt/vol). The optimum activity of tannase obtained from solid and liquid media was 1.441 and $0.603 \mathrm{U} \mathrm{ml}^{-1}$ respectively (Fig 4).

Total soluble protein in solid media was higher than liquid media (Fig 5). The maximum protein content obtained at liquid and solid media when the tannic acid concentration of 5\% (wt/vol) was 0.494 and $0.712 \mathrm{mg} \mathrm{ml}^{-1}$ respectively.

\section{DISCUSSION}

The present study clearly showed that various factors affect tannase production by A. niger isolated from Indonesian cacao pod. Tannase activity at a growth temperature of $28{ }^{\circ} \mathrm{C}$ was higher than that of growth temperature of 26 and $32^{\circ} \mathrm{C}$ but was not different from that of

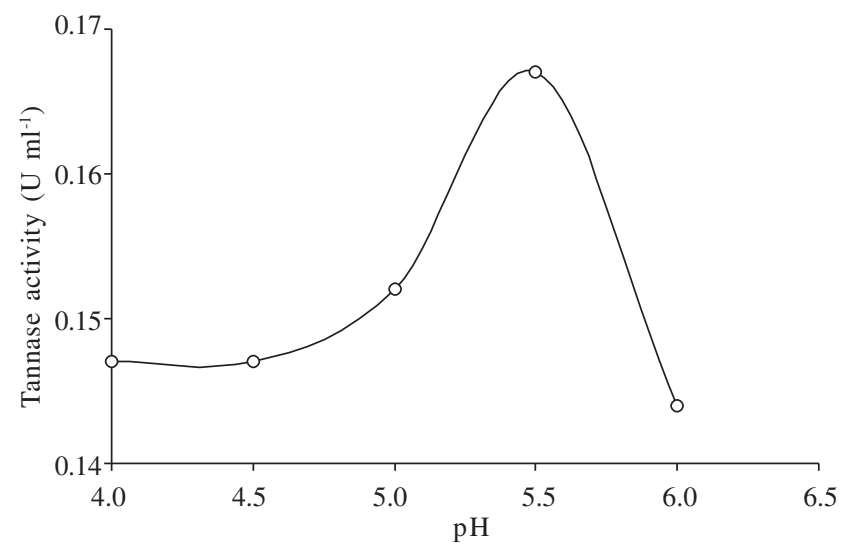

Fig 2 Effect of pH on tannase activity at $28{ }^{\circ} \mathrm{C}$ and 3 days incubation period.

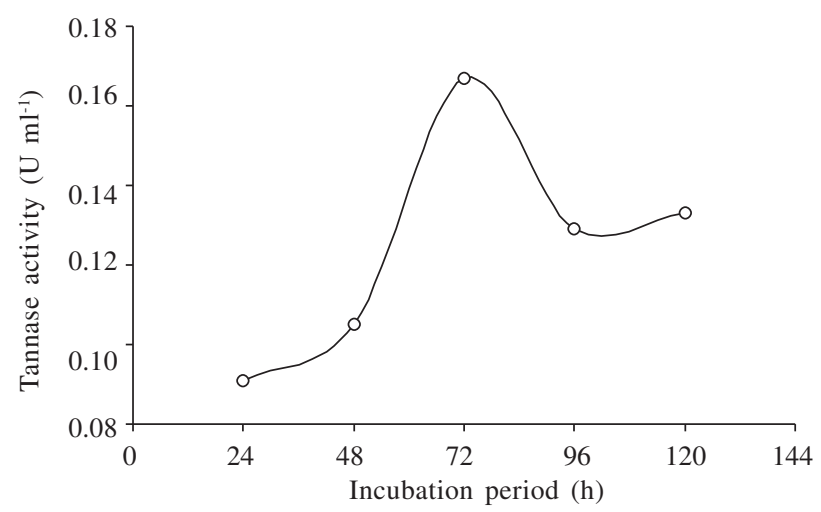

Fig 3 Effect of incubation period on tannase activity at $28{ }^{\circ} \mathrm{C}$ and $\mathrm{pH} 5.5$. 


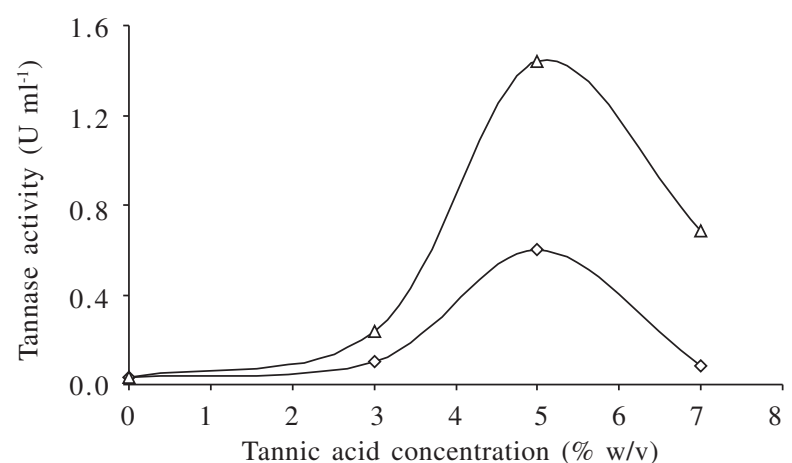

Fig 4 Tannase activity in solid and liquid media using different tannic acid concentrations as inducer. Liqiud media $(\neg)$, solid media $\left(-\triangle^{-}\right)$

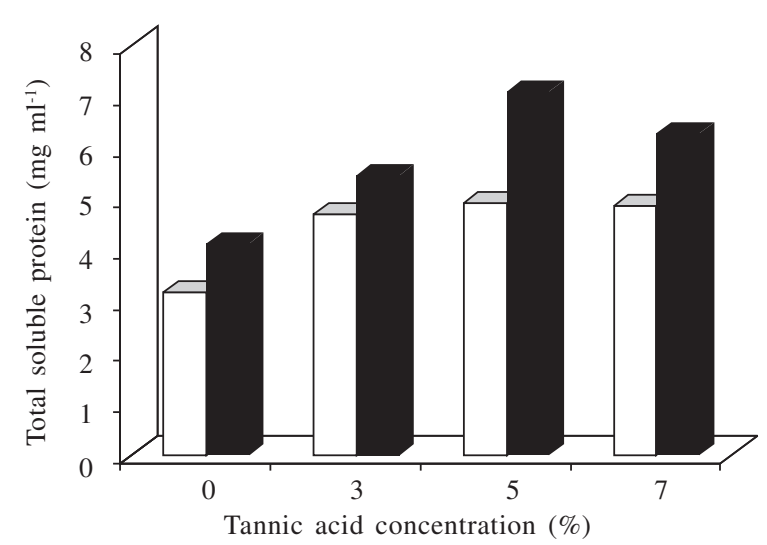

Fig 5 Total soluble protein in solid and liquid media using different tannic acid concentrations as inducer. Liquid media ( $\square)$, solid media ( $(\mathbf{)}$.

$30^{\circ} \mathrm{C}$. Similar results were reported for tannase from A. niger (Lekha and Lonsane 1997; Sanchez 2003). Slightly different results were reported by Banerjee et al. (2005) who found an optimum growth temperature of $30^{\circ} \mathrm{C}$. This was mainly due to the difference in the strain used in the study. They used Rhizopus oryzae and Aspergillus foetidus as tannase producers.

The lower activity of tannase observed at $26^{\circ} \mathrm{C}$ could be due to a lower enzymatic reaction rate leading to lower tannase activity compared to the tannase activity obtained at optimal growth temperature $\left(28^{\circ} \mathrm{C}\right)$. On the other hand, at high temperature, proteins are denatured because of the disruption of their tertiary and quaternary structures, and enzymatic activities decline. In addition, at temperature above the maximal growth temperature, excretion of protease proceeds rapidly so that tannase activity decreases (Mackenzie et al. 1994).

Apart from growth temperature, the $\mathrm{pH}$ value of growth medium also affects tannase activity. Tannase activity was higher in the culture with growth medium with $\mathrm{pH}$ of 5.5 compared to the tannase activity from growth medium with other $\mathrm{pH}$ values. Similar results were reported for tannase from A. niger (Ramirez-Coronel et al. 2003; Sabu et al. 2005). Apparently different results were reported by Sanchez (2003) who found that optimum $\mathrm{pH}$ value for tannase production was 4. It is important, however, to note that in these experiments the $\mathrm{pH}$ values tested were limited to $\mathrm{pH} 4$ and 7 , while the $\mathrm{pH}$ value of 5.5 was not tested (Sanchez 2003).
Optimization of incubation period was carried in order to determine the best time for harvesting tannase from production culture. Incubation period also affects the assayable tannase level. The optimum incubation period was 3 days which was similar to that found by Kar et al. (1999) and Pinto et al. (2001). Different optimum incubation periods, however, were reported by Alberts (2002) and Rana and Bhat (2005). Alberts (2002) found that optimum incubation period was $24 \mathrm{~h}$ while Rana and Bhat (2005) reported maximum tannase production with incubation period of $96 \mathrm{~h}$. The varied optimal incubation period found by different workers might be due to differences in fungal strain and medium composition used for tannase production.

Solid medium was found to be better than liquid medium. This could be due to effect of catabolite repression is less significant in solid medium. The present study showed that solid state fermentation can increase tannase activity about 1.5 folds. In addition, tannase production was affected by concentration of inducer in the medium. The highest tannase activity was found in solid state fermentation with tannic acid concentration of 5\% (wt/vol). Tannase activity was lower at lower $(3 \%, \mathrm{wt} / \mathrm{vol})$ tannic acid concentration. Similarly, at higher $(7 \%, \mathrm{wt} / \mathrm{vol})$ tannic acid concentration the tannase activity decreased indicating that the optimum tannic acid concentration was 5\% (wt/vol). Excessive tannic acid was reported to act as repressor and prevents synthesis mRNA. In addition, the increased of tannic acid causes an increased of heat build up and reduced aeration which in turn decreased productivity of tannase (Banerjee et al. 2005). Similar results were reported previously by Lekha and Lonsane (1994) and Aguilar (2001).

Increased productivity of hydrolytic enzyme in solid media is due rapid oxygen uptake rate which allows fungus to form abundant aerial mycelium. Aerial mycelium gives a strong increase in enzyme production (Rahardjo et al. 2002). In addition, solid media generate higher product stability and lower catabolic repression compared to liquid media (Holker et al. 2004). Moreover, protease activity in solid state fermentation was found to be lower than protease activity in liquid surface fermentation resulting in higher tannase productivity (Aguilar et al. 2002).

\section{REFERENCES}

Aguilar CN, Augur C, Favale-Torres E, Viniegra-Gonzalez G. 2001. Induction and repression patterns of fungal tannase in solid state and submerged cultures. Process Biochem 36:565-570.

Aguilar CN, Augur C, Favale-Torres E, Viniegra-Gonzalez G. 2002. Cultures conditions dictate protease and tannase production in submerged and solid state cultures of Aspergillus niger Aa-20. Appl Biochem Biotechnol 103:407-414.

Alberts EH. 2002. Cloning, expression and characterization of tannase from Aspergillus species. [Thesis]. Bloemfontei: University of the Free State Bloemfontei, South Africa.

Banerjee D, Mukherjee G, Patra KC. 2005. Microbial transformation of tannin rich substrate to gallic acid through co-culture method. Bioresource Technol 96:949-953.

Bradford MM. 1976. A rapid and sensitive method for the quantitation of microgram quantities of protein utilizing the principle of protein dye binding. Anal Biochem 72:248-254.

Butler LG, Rogler JC. 1992. Biochemical mechanisms of the antinutritional effects of tannins. In: Ho CT, Lee CY, Huang MT (eds). Phenolic Compounds in Food and Their Effects on Health 
I: Analysis, Occurrence, and Chemistry. Washington: American Chemical Society.

Hatamoto O, Watarai T, Kikuchi K, Misusawa HS. 1996. Cloning and sequencing of the gene encoding tannase and structural study of the tannase subunit from Aspergillus oryzae. Gene 175:215-221.

Holker U, Hofer M, Lenz J. 2004. Biotechnological advantages of laboratory scale solid state fermentation with fungi. Appl Microbiol Biotechnol 64:175-186.

Kar B, Banerjee R, Bhattarcharyya BC. 1999. Microbial production a gallic acid by modified solid state fermentation. J Indust Microbiol Biotechnol 23:173-177.

Lekha PK, Lonsane BK. 1994. Comparative titres, location, and properties of tannin acyl hydrolase produced by A. niger PKL 104 in solid state, liquid surface and submerged fermentations. Process Biochem 29:497-503.

Lekha PK, Lonsane BK. 1997. Production and application of tannin acyl hydrolase: state of the art. Adv Appl Microbiol 44:215-260.

Libuchi S, Minoda Y, Yamada K. 1966. Study on acyl hydrolase of microorganism III. A new method determining the enzyme activity using a change in ultra violet absorption. Agric Biol Chem 31:513.

Mackenzie DA, Gendron LCG, Jeenes DJ, Archer DB. 1994. Physiological optimization of secreted protein production by Aspergillus niger. Enzyme Microb Technol 16:276-280.
Pinto GAS, Leite SGF, Terzi SC, Couri S. 2001. Selection of tannaseproducing Aspergillus niger strains. Brazilian J Microbiol 32:2426.

Purnama IN. 2004. Studies on potency of fungal isolates to cleave tannin linkage in caccao pod (Theobroma cacao L). [Thesis]. Bogor: Institut Pertanian Bogor, Indonesia.

Rahardjo YSP, Weber FJ, Le Comte EP, Tramper J, Rinzema A. 2002. Contribution of aerial hyphae of Aspergillus oryzae to respiration in a model solid state fermentation system. Biotechnol Bioeng 78:539-544.

Ramirez-Coronel A, Viniegra-Gonzalez G, Augur C. 2003. A novel tannase from Aspergillus niger with $\beta$-glucosidase activity. Microbiology 149:2941-2946.

Rana NK, Bhat TK. 2005. Effect of fermentation system on the production and properties of tannase of Aspergillus niger van Tieghem MTCC 2425. J General Appl Microbiol 51:203-212.

Sabu A, Kiran GS, Pandey A. 2005. Purification and characterization of tannin acyl hydrolase from Aspergillus niger ATCC 16620. Food Technol Biotechnol 43:133-138.

Sanchez HH. 2003. Optimization of Aspergillus niger tannase production using Taguchi methods, abstr Institute of Food Technologists Annual Meeting. Chicago, July 12-16, 2003. Abstr no 76B-23, p 23. 